\title{
Magnus Öhrn
}

\section{Medelklassens buspojkar: en maskulinitetsstudie i Erik Pallins Pojkarna på Klasro}

\author{
http://urn.kb.se/resolve?urn=urn:nbn:se:sbi-40 \\ Citation: Nordic Journal of ChildLit Aesthetics, Vol. 2, 2011 DOI: 10.3402/ \\ blft.v2i0.5842
}

\begin{abstract}
In my article, "Young rascals of the middle-class - masculinities in Erik Pallins Pojkarna på Klasro", I argue that Pojkarna på Klasro (1922) in many regards is a typical boy's book, and a good starting-point for mapping out and studying the Swedish branch of the genre, a genre defined by gender. During the 1920s the Swedish author Erik Pallin (1878-1964) wrote five books about the three brothers Erik, Nisse and Anders, which all take place at the family's summerhouse Klasro during school holidays. The stories mainly revolve around typical boyhood adventures and outdoor activities, such as hiking, exploring, swimming, rowing, and fighting other gangs of boys, in this case, preferably boys of the lower classes. Not surprisingly, Pallin's text describes a patriarchal hierarchy, where the boys are adjusted to hegemonic masculinity and driven by homosocial desire, which leads to the excluding of girls; most female characters play subordinated (anonymous) parts and are bound up with the domestic sphere. In terms of power, an intersectional perspective shows that besides gender, age, physical abilities, geographical domicile (in this case Stockholm) and class are important factors when the boys establish their pecking order. An interesting aspect of the fact that the boys belong to the middle-class, is the lack of typical boy's discourse (slang, puns, oaths etc.), which otherwise is common in Swedish boy's books of this era.
\end{abstract}

Keywords: Swedish boy's book, masculinity, Erik Pallin, boyhood

Den svenska pojkboken har ännu inte blivit föremål för en större studie och inte heller existerar det någon övergripande analys av genren ur ett maskulinitetsperspektiv. Pojkboken är ju, för att travestera det Boel Westin skriver om flickboken i Om flickor för flickor (1994), en text där könet, det gäller såväl författaren som protagonisten 
och läsaren, fungerar som en genrebestämmande kategori (Westin 1994, 10). Syftet med denna artikel är därför att studera ett verk ur pojkboksgenren, Erik Pallins Pojkarna på Klasro (1922), med genuskonstruktionen som utgångspunkt.

Den teoretiska ramen för denna analys är hämtat från den samtida teoribildningen inom mansforskningen. Utgångspunkten här, som i de flesta studier i manlighet, är det som bland annat Thomas Johansson påpekar i Det första könet? (2000), nämligen att behandla manlighet "som en social och historisk och därmed variabel konstruktion" (Johansson 2000, 27). Tanken på könet som en historiskt föränderlig konstruktion är främst hämtad från Judith Butlers Gender trouble (1990), där hon menar att kön endast existerar i de framträdanden (performances) vi utför (Butler 1990). Genuspositionerna byggs således upp via olika språkliga representationer, i det här fallet pojkbokstexterna.

Här, som i andra undersökningar av de manliga konstruktionerna, aktualiseras maktperspektivet och ett verksamt begrepp för att analysera över- och underordning är hegemonisk maskulinitet. Begreppet, som introducerades i R. W. Connells Masculinities (1995, på svenska 1996), definieras "som den konfiguration av genuspraktik som innehåller det för tillfället accepterade svaret på frågan om patriarkatets legitimitet." (Connell 1996, 101) Det rör sig alltså om mäns överordnade position gentemot kvinnor, men också gentemot andra män. Connell menar att den hegemoniska maskuliniteten är utgångspunkten för alla olika manlighetstyper eller maskuliniteter, att det handlar om idealbilder som mannen har att förhålla sig till; men det "innebär inte att de mest iögonfallande bärarna av hegemonisk maskulinitet alltid är de mäktigaste. De kan lika gärna vara ideal såsom filmskådespelare eller till och med fantasifigurer" (ibid, 101).

Ett annat viktigt begrepp i detta sammanhang är intersektionalitet, ett analytiskt hjälpmedel som synliggör hur de olika maktordningarna är sammanflätade på olika nivåer. Ett intersektionellt perspektiv tar hänsyn till hur makt vävs in i uppfattningen om olika identitetskategorier, såsom kön, klass och etnicitet; andra viktiga kategorier i pojkbokens värld är ålder, geografisk hemvist (stadland), kroppsliga företräden (styrka, längd etc.) och att behärska olika fysiska aktiviteter.

Liksom män föredrar pojkar varandras sällskap, något som undersöks med hjälp av begreppet homosocialitet, vilket avser att män föredrar att umgås med andra män och känner sig stimulerade och inspirerade av detta umgänge. I Michael S. Kimmels Manhood in America (1996) understryks att konstruktionen av manlighet i hög 
grad är en homosocial företeelse, det är i den manliga gruppen man får status och bekräftas. Ytterligare ett verksamt begrepp i detta sammanhang är manligt homosocialt begär (male homosocial desire), lanserat av Eve Sedgwick i Between Men (1985), vilket innebär ett ifrågasättande av åtskillnaden mellan homosocialitet och homosexualitet. Sedgwick menar, för att uttrycka det som Ingrid Holmquist i "Mellan män" (2005): "att homosocialt begär bör ses som ett kontinuum av känslor, där homosocial närhet innehåller en begärspotential som kan övergå i homoerotik" (Holmquist 2005, 67).

En annan viktig utgångspunkt i min undersökning är tanken på ett pojkland, de territorier där pojkarna vistas utan vuxeninblandning och där en pojkarnas egen subkultur utvecklas. Idén är hämtad från den amerikanske historikern E. Anthony Rotundos studie "Boy culture: middle-class boyhood in nineteenth-century America" (1990). Här pekas flera olika utvecklingslinjer ut, kopplade till marknadsekonomins och medelklasskulturens framväxt i början av 1800-talet, som påverkade pojkarnas värld både till form och innehåll. En sådan process var att mannen, som under 1700-talet haft ansvaret för sönernas uppfostran, blev alltmer frånvarande i pojkarnas värld. Samtidigt utvecklades en distinkt kvinnlig sfär i hemmen i början av 1800-talet och mödrarna, som tidigare hade ansetts klema bort sina söner, fick nu ett större uppfostringsansvar. För ynglingen innebar detta en märklig kombination av influenser, han växte upp i en värld som stod i skarp kontrast till den han skulle verka i som vuxen: "He was raised by a woman to become a man." (Rotundo 1990, 33) I tre olika artiklar har jag visat att Rotundos idéer delvis är överförbara på en svensk kontext, både vad gäller äldre och nyare barnlitteratur (Öhrn 2008a, 2009, 2010).

En av de som på svensk botten studerat pojkboken ur ett maskulinitetsperspektiv är Marika Andræ, vilket sker i avhandlingen Rött eller grönt?: flicka blir kvinna och pojke blir man $i$ B. Wahlströms ungdomsböcker 1914-1944 (2001), vars senare del utgörs av en genusstudie av B. Wahlströms pojkböcker under sagda period, både svenska och översatta. Andræ påpekar att svensk pojkboksforskning utgör "ett magert kapitel" (Andræ 2001, 275), vilket också understryks av Boel Westin i sin recension av Andræ i Samlaren (2001): "pojkboksforskningen [är] inte alls lika utvecklad som flickboksforskningen; det finns ett stort behov av undersökningar av pojkboken som litterärt fenomen och könsbestämd genrekategori." (Westin 2001, 151) Andra vikiga bidrag till den svenska pojkboksforskningen är Conny Svenssons Pli på pojkar (2008), som framförallt riktar in sig på det manligt fostrande inslaget $\mathrm{i}$ både svenska och översatta äldre 
pojkböcker, och Ulf Boëthius artiklar om manlighetsbegreppet 1930-talets svenska flygböcker för pojkar, såsom "Med nerver av stål: manlighet och modernitet i 1930-talets svenska flygböcker för pojkar" (1999).

\section{Erik Pallin och Pojkarna på Klasro}

Erik Pallins Pojkarna på Klasro är på flera sätt lämpig som exemplum vid en studie av den svenska pojkboken.

För det första stämmer texten in på den genredefinition som skulle kunna ligga till grund för ett materialurval vid en mer övergripande studie av den svenska pojkboken. Den har nämligen av förlaget marknadsförts som en sådan, det vill säga att ordet "pojkbok" eller likartade benämningar anges i paratexten. Jag utgår således från den genredefinition som Birger Hedén anmäler i artikeln "Vad är en pojkbok?", närmare bestämt hans punkt 1 och 2: "1) Ordet pojkbok eller likartade uttryck som 'för pojkar', 'för gossar', 'pojkläsning' anges i boktiteln, på omslaget, på titelsidan, i baksidestexten, i annons eller annat jämförbart sammanhang. 2) Boken kan ingå i en serie, kallad t ex Pojkars läsning eller dylikt." (Hedén 1989, 7)

Den fullständiga titeln på Pallins bok, Pojkarna på Klasro: en berättelse om sjörövarliv, båtkrig och äventyr på landstället, består av en rad pojkboksmarkörer, såsom att ordet "pojkar" ingår i titeln och att honnörsord som "sjörövare", "krig" och "äventyr" finns med i undertiteln. Benämningen "pojkbok" får den i och med att nästa del i serien kommer ut året därpå, på baksidan av denna räknas den upp som en av titlarna under rubriken: "På ÅHLÉN \& ÅKERLUNDS FÖRLAG har förut utkommit följande pojkböcker av ERIK PALLIN" (Pallin 1923).

För det andra ingår Pojkarna på Klasro i en serie böcker om samma karaktärer, något som tycks ha varit vanligt när det gäller både flick- och pojkböcker. Det är den första boken av fem som handlar om de tre bröderna Erik, Nisse och Anders. Erik är berättarjaget, vilket ger det hela en självbiografisk prägel, något som förstärks av att Erik Pallins bröder hette just Nils och Anders. De övriga i sviten är Klasropojkarna på äventyr (1923), Pojkarna på Fridhem (1924), Klasropojkarnas jullov (1925) och Klasropojkarna på det gamla vraket (1926). I korthet rör det sig om episodiska vardagsäventyr som utspelar sig under skollov på landstället Klasro. Subgenremässigt uppvisar texterna framförallt drag från två olika håll: gängskildring och rackarungeberättelse. I Rött eller grönt? finner Andræ att berättelser om pojkgäng ofta är uppbyggda enligt samma princip: 
"Den gemensamma historien i berättelser om unga pojkar består främst av episoder koncentrerade till olika aktiviteter i gänget." (Andræ 2001, 177) Denna beskrivning stämmer väl in på Pojkarna på Klasro, det vill säga det rör sig återigen om en litterär gestaltning av manligt homosocialt begär. I Lars Furuland, Mary Ørvig och Sonja Svenssons Ord och bilder för barn och ungdom 3: Ungdomslitteraturen (1994) placeras boken under rubriken "Rackarpojkar", vilket är en adekvat genrebeskrivning i det här fallet, även om flertalet av deras busstreck är långt harmlösare än i andra rackarungeberättelser.

För det tredje gavs boken ut under 1920-talet, decenniet då mycket talar för att den svenska pojkboken etableras på allvar. Detta framkommer exempelvis hos Hedén, av de fyra författare han menar "spelat en betydande roll för pojkbokens utveckling" är tre som mest aktiva under denna period: Ebbe Lieberath, Hjalmar Wallander och just Erik Pallin (Hedén 1989, 5). 1920-talet utgör också en vit fläck på forskningskartan. Ser man till en av få undersökningar som sträcker sig över decenniet ifråga, nämligen Andræs Rött eller grönt?, behandlas endast fyra svenska pojkböcker från denna epok.

För det fjärde förefaller Erik Pallin (1878-1964) på flera sätt vara en typisk representant för sitt skrå. Precis som flera av sina samtida kollegor var han inte pojkboksförfattare på heltid, utan hade det som en bisyssla. I likhet med exempelvis Sigge Strömberg och Axel Kerfve var Pallin tidningsman. Han skrev en lång rad artiklar och böcker under signaturen "Flying" och brukar räknas som Sveriges första flygjournalist. Vidare kan man säga att hans ungdomslitterära produktion dog med honom, vilket är fallet med flertalet av hans samtida kollegor. Epokens pojkboksförfattare och deras verk har heller inte satt några större avtryck i de barnlitteraturhistoriska översiktsverken. I Eva von Zweigbergks Barnboken i Sverige 17501950 (1965) nämns Pallin överhuvudtaget inte och hos Furuland, Ørvig och Svensson ägnas han endast några rader, där det konstateras att hans böcker inte överlevt och som ett kvitto på detta ges den här aktuella boken fel titel: "Pojkarna på Klasbo" (Furuland m fl 1994, 186).

\section{Manliga förebilder}

Redaninledningsvisfårläsaren enlektioni hegemoniskmaskulinitet och hur bröderna relaterar till den manliga hierarki som gestaltas i texten. Vid ett par tillfällen stöter de ihop med styrmannen på Nordkusten, den båt som ska ta dem till landstället Klasro, men det är möten som inte faller väl ut: "Det var en otrevlig en, tyckte vi, men 
pappa kände välan kapten, så att nog skulle väl han få igen det där." (Pallin 1922, 26) Det är uppenbart att bröderna, via sin mestadels osynlige fader, är predestinerade till en högre samhällsklass än den styrmannen representerar.

Texten markerar också rangordningens gränser inom den manliga hierarkin och vad som sker om man överskrider dessa; alltså indirekt vilka manligheter som ges en dominerande position i förhållande till de övriga.

I detsamma gick den elake styrmannen förbi.

»Håll an där, Johnsson», sade kaptenen, »här ä Johans pojkar, som ska med till Gävle. Se till dem lite hyggligt under resan, är du snäll.»

Vi hälsade naturligtvis, och Nisse knuffade till mig och sade: »Där fick han välan, va?» (43)

De unga pojkarna omfattas således redan av hierarkins kodex. Kaptenens åthutning innebär att styrmannen försvinner ur historien och istället vistas bröderna mestadels på kommandobryggan. En närmast övertydligt symbolisk plats där pojkarna på olika sätt är kaptenen behjälplig med att styra båten mot Gävle.

När de kommer till Klasro dyker en ny manlig förebild upp, deras kusin Viktor, 17 år. Han beskrivs som "mycket skojig" av berättarjaget medan pojkarnas pappa menar att han är en "vildbasare" (71). Viktor utgör således en länk mellan männens värld och pojkarnas. Då Viktors far är död har han axlat en del av den vuxne mannens ansvar och agerar ställföreträdande pappa åt bröderna. Han ordnar exempelvis en verkstad där de kan hållas med sina modellbåtar och han hjälper dem att sätta kölar på båtarna. Men Viktor är också pojke och som den äldre i kretsen åligger det honom att visa stockholmsbröderna pojklandet runt Klasro. Hans första åtgärd blir därför att föra pojkarna bort från hemmets kvinnodominerade intimsfär. I Pojkarna på Klasro är vattnet och vattenlinjen pojklandets främsta domäner. Viktor förevisar omgivningen och introducerar de mer eller mindre äventyrliga aktiviteter som topografin erbjuder, som att ro under bryggan. Samtidigt styrs Viktor av sitt vuxenansvar, han instruerar exempelvis pojkarna hur man vickar sig loss från ett grund. Emellanåt är han dock hårdhänt kamratuppfostrare, som när minstingen Anders ramlar i vattnet och Viktor inte omedelbart plockar upp honom: "Han kan gärna hålla på en stund så där, sade Viktor, så lär han sig, att man skall sitta i båtar." (79) På ett hårdhänt sätt passar han på att ge Anders en läxa. 
Både kaptenen och Viktor är högst påtagliga manliga förebilder men när man talar om maskulin hegemoni avser man oftast ideal ingen kan leva upp till men som de flesta ändå söker förhålla sig till. I pojkböckerna är det vanligt att dessa fantombilder tar gestalt i olika typer av idoler, både historiska, ofta då i mytogen form, och fiktiva hjältar. Redan i inledningen av Pojkarna på Klasro möter man en sådan idol ombord på en av brödernas modellbåtar: "Amiralen hette Osman Pascha och var vår stiligaste tennsoldat." (12) Förebilden är OsmanNuri pascha ghasi (1832-1900), en turkisk fältmarskalk. Längre fram förekommer en tennsoldat uppkallad efter den engelske generalen Hector Mac Donald (1852-1903). Möjligen kan denna upphöjelse av militära ledare som manligt ideal i pojkboken ses som en ideologisk rest från 1800-talet. Intressant är dock hur Klasropojkarna använder dessa i sina lekar, där de används helt frikopplade från sina historiska kontexter och mer står som symboler för manliga ideal: "och på toppen av fortet Tre kronor stod själva Osman pascha med dragen sabel." (122)

\section{Förhållandet till det kvinnliga}

Även om de tre bröderna inte har någon mamma, något som inte kommenteras, är de omgivna av olika modersgestalter som på olika sätt sätter upp regler och gränser för dem. I stockholmshemmet är det faster Hilma som representerar intimsfären och vars mission tycks vara att hålla dem rena, det vill säga utplåna de spår som aktiviteterna i pojklandet resulterat i. När de bordar båten för sin resa står hon på kajen och söker utvidga sin jurisdiktion till Klasro:

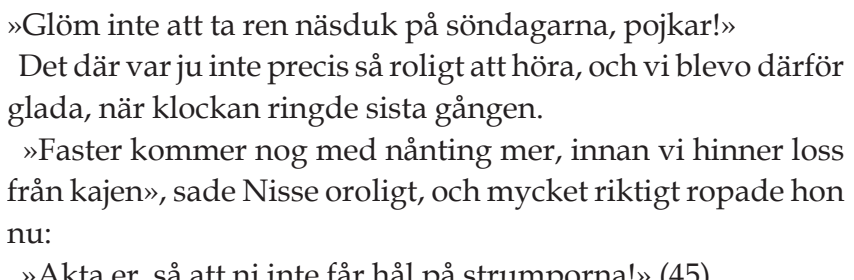
»Akta er, så att ni inte får hål på strumporna!» (45)

Men ombord på båten har fadern sett till att en annan kvinna står för omvårdnaden, städerskan Tilda och väl framme på landstället är det deras moster Charlotte som sätter upp reglerna. Hon ger pojkarna en större frihet än de är vana vid, vilket dels kan förklaras med skollovet som en undantagstid, dels med att hon är änka, det vill säga hon har axlat vissa av sin bortgångne mans maktfunktioner. Hon ger bröderna ett eget hus att bo i: 
"Vid gränsen mellan köksträdgården och skogen låg ett hus, där det fanns vedbod, vagnslider etc. samt även ett boningsrum, och här skulle vi få bo." (71) Symptomatiskt talar berättarjaget Erik om en "gräns", som i detta sammanhang kan tolkas som skranket mellan intimsfären (köksträdgården) och pojklandet (skogen).

Men Charlotte har inte helt släppt den övervakande funktion som hör modern till, "klockan nio på kvällen ska ni vara inne och i säng." (71) Intressant är att när bröderna bryter mot denna regel och sånär blir påkomna av Charlotte saknas den traditionella buspojkens mod och frejdighet: "Vad skulle vi nu ta oss till? Ge oss tillkänna och tala om att vi varit olydiga - nej, det vågade vi icke." (155)

De jämnåriga flickor som förekommer i handlingen betraktas mestadels som ett opersonligt kollektiv. När de får veta att Klasropojkarna har kanoner som det går att skjuta med, reagerar denna anonyma massa: "Hu då, hördes en röst från flickorna." (103). Ett mer illustrativt exempel på detta betraktelsesätt finner man i uppföljaren Klasropojkarna på äventyr, där de benämns "flickbunten" (Pallin 1923, 63).

Men trots detta ointresse anas en vag spänning mellan könen. När flera av brödernas modellbåtar kapsejsar vid premiärturen i Klasros farvatten, står en mängd grannpojkar på bryggorna och skrattar. Men detta är inte det värsta: "Och där stod några flickor också bland dem - o, så förargligt." (92) Att det skulle vara värre att misslyckas inför flickor skulle kunna tolkas som att man som pojke bör imponera på dem, vilket i sin tur skickar signaler om det sexuella spel mellan könen som ännu ligger i en avlägsen framtid. Man bör dock hålla i minnet att den vuxne manlige författaren emellanåt ger hugg på sig, inte minst via den manliga blick som ger sig till känna i beskrivningen av moster Charlotte: "Hon var väl några och fyrtio år nu, men såg väldigt bra ut." (70) Detta är knappast en reflexion av en pojke i mellanåldern.

\section{Homosocialt begär och klass}

Den till synes viktigaste förutsättningen för pojkarnas gängbildningar är att de är just pojkar, men skärskådar man den homosociala aktiviteten ur ett intersektionellt perspektiv finner man att en rad andra kategorier är i spel.

Den minsta enheten är brödratrion, vilket visar att familj/släkt i detta fall är av vikt. Ålder, som ofta är en förbisedd maktkategori i intersektionella studier (se Krekula, Närvänen \& Näsman 2005), spelar ofta en underordnad roll i konsolideringen av pojkgängen $i$ Pojkarna på Klasro. Man får tidigt veta brödernas åldersordning: "Jag 
fick betyg till fyran, Nisse till trean och Anders till andra klass." (15f) Härav kan man sluta sig till att de går på läroverk och att de troligtvis är i åldrarna 11, 10, 9 år, men åldern utgör i sig ingen anledning till att utesluta någon ur gemenskapen. Däremot utgör de betydelser olika åldrar tillskrivs en grundval för hur pojkgängets hierarki struktureras dvs. den interna maktfördelningen. På olika sätt blir det tydligt att berättarjaget Erik, som varande äldst, har en ledarfunktion, vilket i sin tur innebär ett visst ansvar. Ett illustrativt exempel på brödratrions maktordning finner man i följande: "Först tittade jag, så Nisse och sist Anders, som vi höllo i rocken för säkerhets skull, så att han inte skulle ramla i." (46) När bröderna blir kompisar med pojkarna på Fridhem, landstället bredvid, är ålder av underordnad betydelse, utom i ett fall: "Jämnårig med mig var Bror, och honom tyckte vi med detsamma om." (100) Det tycks således vara viktigt att markera att ingen är äldre än berättarjaget, att maktbalansen är orubbad.

En viktigare kategori än ålder när det gäller förutsättningarna för pojkarnas gruppbildningar ligger i de innebörder man tillskriver geografisk hemvist. Att det är viktigt var man bor markeras tidigt i historien: "När pojkar från andra kvarter försökte tränga sig fram, fingo de smörj." (10) Här står det klart att det första man gör när man möter andra gäng är att på något sätt utmana dem, att exempelvis med våld markera det egna gängets sammanhållning och territorium.

Även om pojkarna från Klasro och Fridhem snabbt smälter samman till en homosocial enhet, markeras emellanåt att det finns en tydlig skiljelinje som just handlar om var man bor. När de leker kurragömma tillsammans söker Erik hålla sig gömd så länge som möjligt: "Det vore väl dåligt, om ett par stockholmsgrabbar skulle låta ta sig i första klippet." (106) Denna inställning skvallrar om att Erik, i egenskap av stockholmsbo, anser sig stå högre upp i pojkhierarkin.

Intrycket förstärks när de två pojkgrupperna ska leka med tennsoldater. Då de ska delas upp i anfallande sjörövare och soldater som ska försvara fästningen Gibraltar, hittar Josef en tennsoldat "svart i ansiktet som en neger" och placerar denna bland piraterna. Detta väcker oerhörd indignation bland Klasropojkarna.

Vi tre bröder tittade häpna på varandra. Ty detta var väl ändå bra starkt. Kalla general Mac Donald, vår kanske allra tappraste härförare, för en neger! Det var oerhört.

»Neej, vet du vad, Josef, nu är du oförskämd helt enkelt», sade Anders. »Neger kan du vara själv.»

»Det märks, att du är från landsorten», sade Nisse. (124) 
Den etnocentriska världsbild som bröderna vädrar är inte ovanlig $i$ pojkböcker från denna tid. Vad som är intressant är att den här även tycks omfatta de territorier som ligger utanför Stockholm, den vita rasens överlägsenhet parallelliseras med storstadsbons överhöghet gentemot landsortsbon. Men om det är tapperhet som skiljer den vite mannen från den färgade, är det här snarare fråga om en klyfta av okunskap som drar gränsen mellan stad och land. Josef känner uppenbarligen inte till den engelske generalen, som var synnerligen aktiv i den koloniala krigföringen i Afrika, och förstår därmed inte det "oerhörda" $i$ att likna honom vid en neger.

Det visar sig alltså att geografisk hemvist, etnicitet och nödiga kunskaper (meritokrati) spelar in när det gäller de homosociala och hierarkiska strukturerna som gestaltas i texten. Alla dessa kategorier hänger i sin tur samman med klass. Klassperspektivet genomsyrar hela historien, något som markeras redan i bokens undertitel, det handlar om pojkars äventyr på ett landställe.

Härefter står klassmarkörerna tätt. Pojkarna bor på Östermalm och går på läroverk, något som bara en liten andel av svenska ynglingar gjorde vid denna tid. Intressant i sammanhanget är att det går bra för dem i skolan. Som exempelvis Conny Svensson visat i Pli på pojkar är aversionen mot skolan närmast en pojkbokskonvention, här avviker således Pojkarna på Klasro från genren i stort.

Klasstillhörighet är också motorn i flera av de äventyr som pojkarna hamnar i. För att få med sig modellbåtarna till Klasro gör de i ordning ett stort paket som de bär ner till båten natten innan avgång. Vägen från Östermalm till Skeppsbron utvecklas till något av en Golgatavandring, där de åtföljs av ett gäng "gatpojkar":

På Luntmakargatan skreko grabbarna: »Akta er, här kommer snobbar på väg till pantbanken med ett piano, som dom rullat tidningar om. Hitåt kvantingar å titta!»

Sådant var ju inte så roligt att höra precis. Eller när de ropade: »Kikus på östermalmarna, som är ute för att sälja farsans byrå.» (35)

Den pojkdiskurs som jag sökt kartlägga i min artikel "'Har du börjat ruttna i kolan?"' (2008), vilken röjs bakom fenomen som slang, namngivning och ordvitsande och som man finner prov på i 1920-talets pojkböcker (i synnerhet hos Ebbe Lieberath), ligger här endast i munnen på gatpojkarna. Detta i sin tur understryker och fördjupar det klassgap som gestaltas i texten. Frånvaron av pojkdiskurs hos berättaren och huvudkaraktärerna bör dock också ses 
i ljuset av författarens fostrande roll, det handlar inte enbart om att berätta moraliskt uppbyggliga historier utan att även göra det på "riktig svenska". Ett kvitto på att Pallin var lyckosam i detta fall hittar man i en recension av Pojkarna på Fridhem, signerad Gurli Linder: "hans språk är ett gott exempel på att man kan berätta friskt, muntert och målande utan vulgaritet och utan överflöd av slang." (Linder 1925, 216)

Det avslutande äventyret i Pojkarna på Klasro kan läsas som en vedergällning mot den klass som trakasserade brödraskaran i inledningen. När det visar sig att en av deras modellbåtar är borta dras snabbt slutsatsen att det är sågverkspojkarna på andra sidan sundet som stulit den. Med kusin Viktor som ledare företas en nattlig kommandoraid i "fiendeland", där bland annat en sågverksgrabb tas tillfånga. De tar tillbaka båten och lyckas undkomma förföljarna.

\section{Avslutning}

Även om Pojkarna på Klasro på ett generellt plan uppvisar drag som framstår som typiska för den svenska pojkboken (en bortglömd manlig författare skriver om pojkar för pojkar, vilket signaleras via bokens titel och förlagets marknadsföring), är analysunderlaget för knappt för att nå fram till en bredare konklusion vad gäller genren i vårt land.

Vad artikeln bidrar med är att peka ut vad som ur ett maskulinitetsperspektiv är karakteristiskt för just denna pojkbok. Man finner då att den maskulina hegemonin tydliggörs på olika sätt, vare sig det gäller fantasifigurer, som mytologiserade fältherrar, eller verkliga, som kaptenen på båten Nordkusten. De yngre (jämnåriga) kvinnorna marginaliseras och anonymiseras, medan pojkarna på olika sätt gör uppror mot den omsorg som de äldre kvinnorna (moderssubstituten) representerar. Denna marginalisering (som också drabbar de lägre samhällsklasserna och karaktärer av annat etniskt ursprung) är delvis en konsekvens av att historien i mångt är en gestaltning av manligt homosocialt begär, pojkarna agerar inom och får bekräftelse och status via umgänge inom ett homogent pojkkollektiv.

Jämför man detta med bredare undersökningar gjorda på långt mer omfattande material, såsom Mette Winges Dansk børnelitteratur 1900-1945 - med særlig henblick på børneromanen (1976), finner man uppenbara överensstämmelser. Winge visar att de danska pojkböckerna vid samma period präglas av en hegemonisk medelklassmaskulinitet, där kvinnor/flickor, "lavere placerat socialgrupper" 
och "fremmede (farvede) folkeslag" på olika sätt marginaliseras. Biografisk information: Magnus Öhrn, fil dr, universitetslektor i litteraturvetenskap, särskilt barnlitteratur vid Institutionen för litteraturvetenskap och idéhistoria vid Stockholms universitet.

Kontakt:magnus.ohrn@littvet.su.se

\section{Bibliografi}

Andræ, Marika. Rött eller grönt?: flicka blir kvinna och pojke blir man i B. Wahlströms ungdomsböcker 1914-1944. Skrifter utgivna av Svenska barnboksinstitutet, 73. Diss., Stockholm: B. Wahlströms bokförlag, 2001.

Boëthius, Ulf. "Med nerver av stål : manlighet och modernitet i 1930-talets svenska flygböcker för pojkar". I Barnkultur: igår, idag, i morgon. red., Anne Banér. Stockholm: Centrum för barnkulturforskning, 1999, s. 103-118.

Butler, Judith. Gender trouble: feminism and the subversion of identity. New York: Routledge, 1990.

Furuland, Lars, Ørvig, Mary \& Svensson, Sonja. Ord och bilder för barn och ungdom 3. Ungdomslitteraturen: historik, kommentarer, texturval. Stockholm: Rabén \& Sjögren 1994.

Hedén, Birger. "Vad är en pojkbok?: en projektbeskrivning". Barnboken 12 (1989) 1: 4-7.

Holmquist, Ingrid. "Mellan män: en läsning av Hjalmar Gullbergs dikt 'Kyssande vind'". Tidskrift för litteraturvetenskap (2005) 4: 62-70.

Johansson, Thomas, Det första könet?: mansforskning som reflexivt projekt. Lund: Studentlitteratur, 2000.

Kimmel, Michael S. Manhood in America: a cultural history. New York: Free Press, 1996.

Krekula, Clary, Närvänen, Anna-Liisa \& Näsman, Elisabet, "Ålder i intersektionell analys". Kvinnovetenskaplig tidskrift 2-3 (2005): 82-90.

Linder, Gurli. "Böcker för barn och ungdom julen 1922". Biblioteksbladet: tidskrift för Sveriges allmänna biblioteksförening 8 (1923): 72-81.

Gurli Linder. "Skol- och barnbibliotek". Biblioteksbladet: tidskrift för Sveriges allmänna biblioteksförening 10 (1925): 211-216.

Pallin, Erik. Pojkarna på Klasro: en berättelse om sjörövarliv, båtkrig och äventyr på landstället. Stockholm: Åhlén \& Åkerlund, 1922.

Pallin, Erik. Klasropojkarna på äventyr: andra sommarens sjörövarliv, båtkrig och äventyr på landstället. Stockholm: Åhlén \& Åkerlund, 1923.

Rotundo, E. Anthony. "Boy culture: middle-class boyhood in nineteenthcentury America". In Meanings for manhood: constructions of masculinity in Victorian America. Ed. Chicago: University of Chicago Press, 1990, 15-36. 
Sedgwick, Eve. Between men: English literature and male homosocial desire. New York : Columbia UP, cop. 1985.

Svensson, Conny, Pli på pojkar: från Dumas till Kar de Mumma. Skrifter utgivna av Svenska barnboksinstitutet, 102. Stockholm: Atlantis, 2008.

Westin, Boel, "Flickboken som genre". I Om flickor för flickor: den svenska flickboken. Skrifter utgivna av Svenska barnboksinstitutet, 52. Stockholm: Rabén \& Sjögren, 1994.

Westin, Boel. recension av Marika Andræs Rött eller grönt?: flicka blir kvinna och pojke blir man i B. Wahlströms ungdomsböcker 1914-1944. I Samlaren 122 (2001): 147-152.

Winge, Mette. Dansk børnelitteratur 1900-1945 - med særligt henblik på børneromanen. Köpenhamn: Gyldendal, 1976.

Zweibergk, Eva von. Barnboken i Sverige 1750-1950. Stockholm: Rabén \& Sjögren, 1965.

Öhrn, Magnus. "'Men vad i himlens namn har ni för er, pojkar!': Ulf Starks uppväxtskildringar ur ett manlighetsperspektiv". I Barnlitteraturanalyser, Lund: Studentlitteratur, 2008a.

Öhrn, Magnus. "'Har du börjat ruttna i kolan?: om värderingen av pojkdiskursen i svensk barn- och ungdomslitteratur". I Samlaren 129 (2008b): 305-314.

Öhrn, Magnus. "I pojklandet: en första kartläggning av pojkarnas territorium i svensk barn- och ungdomslitteratur". Tidskrift för litteraturvetenskap (2009) 1: 35-46.

Öhrn, Magnus. "Från mammas kjol till pappas like: pojkdomens livslinje i äldre svensk barnlitteratur". I Livslinjer: berättelser om ålder, genus och sexualitet, Göteborg \& Stockholm: Makadam, 2010.

Note: This article is being published simultaneously in Barnboken - tidskrift för barnlitteraturforskning/Journal of Children's Literature Research and Nordic ChildLit Aesthetics/Barnelitterært forskningstidsskrift 